\title{
Growth and yield of the cowpea cultivar BRS Guariba inoculated with rhizobia strains in southwest Piauí
}

\section{Crescimento e produtividade de feijão-caupi cultivar BRS Guariba inoculado com estirpes de rizóbio no sudoeste do Piauí}

\author{
Elaine Martins da Costa ${ }^{1 *}$; Rafaela Simão Abrahão Nóbrega ${ }^{2,3}$; \\ Linnajara de Vasconcelos Martins Ferreira ${ }^{1}$; Francisco Hélcio Canuto Amaral ${ }^{1}$; \\ Júlio César Azevedo Nóbrega ${ }^{2,3}$; Alessandro Franco Torres da Silva ${ }^{4}$; \\ Fatima Maria de Souza Moreira ${ }^{5}$
}

\begin{abstract}
The interaction of cowpea with efficient strains of rhizobia in biological nitrogen fixation can allow increased yield, which can completely replace nitrogen fertilization and can reduce production costs. The aim of this study was to evaluate the response of cowpea cultivar BRS Guariba to inoculation with six strains of rhizobia (UFLA 03-164, UFLA 03-154, INPA 03-11B, UFLA 03-84, BR 3267 and BR 3262) in a field experiment conducted in the Southwest of Piauí. The experimental design was randomized blocks with eight treatments and four replicates, including the six cited strains and two uninoculated controls, one with mineral nitrogen $\left(70 \mathrm{~kg} \mathrm{ha}^{-1}\right)$ and the other without mineral nitrogen. Nodulation, growth, yield, nitrogen accumulation in shoots and in grains and crude protein content in grains were evaluated. Strains under selection (UFLA 03-154 and UFLA 03-164) promoted yields that were higher compared to those obtained by strains authorized as inoculants (INPA 03-11B, BR 3267 and BR 3262). Inoculation with strains UFLA 03-84, UFLA 03-154 and UFLA 03-164 promoted yields equivalent to the control with mineral nitrogen $\left(796.51 \mathrm{~kg} \mathrm{ha}^{-1}\right)$ and similar to the yield obtained with the control without mineral nitrogen and without inoculation, indicating efficient symbiosis of the indigenous rhizobia. UFLA 03-154 was better than the other treatments in terms of increased crude protein.
\end{abstract}

Key words: Vigna unguiculata (L.) Walp, Bradyrhizobium, biological nitrogen fixation

\section{Resumo}

A interação do feijão-caupi com estirpes de rizóbio eficientes na fixação biológica de nitrogênio pode permitir o aumento da sua produtividade, sendo possível substituir totalmente a adubação nitrogenada e reduzir os custos de produção. Objetivou-se avaliar a resposta do feijão-caupi cultivar BRS Guariba à inoculação com seis estirpes de rizóbio (UFLA 03-164, UFLA 03-154, INPA 03-11B, UFLA 03-84, BR 3267 e BR 3262) em experimento conduzido em campo no Sudoeste do Piauí. O delineamento

${ }^{1}$ Eng $^{\text {os }}$ Agr $^{\text {os }}$, Discentes do Curso de Doutorado em Ciência do Solo, Universidade Federal de Lavras, UFLA, Lavras, MG, Brasil. E-mail: elainemartins20@hotmail.com; linnajaravasconcelos@hotmail.com; helcioagro@gmail.com

${ }^{2}$ Eng $^{\mathrm{a}}$ Agr ${ }^{\mathrm{a}}$, Prof ${ }^{\mathrm{a}}$, Universidade Federal do Recôncavo da Bahia, UFRB, Centro de Ciências Agrárias, Ambientais e Biológicas, Cruz das Almas, BA, Brasil. E-mail: rafaela.nobrega@ufrb.edu.br

${ }^{3}$ Eng $^{\circ}$ Agr $^{\circ}$, Prof., Universidade Federal do Recôncavo da Bahia, UFRB, Centro de Ciências Agrárias, Ambientais e Biológicas, Cruz das Almas, BA, Brasil. E-mail: juliocnobrega@gmail.com

${ }^{4}$ Eng $^{\circ}$ Agr $^{\circ}$, M.e em Solos e Nutrição de Plantas, Universidade Federal do Piauí, UFPI, Campus Prof Cinobelina Elvas, CPCE, Bom Jesus, PI, Brasil. E-mail: alefrancotorres@hotmail.com

${ }^{5}$ Eng $^{\text {a }}$ Agr $^{\text {a }}$, Pesquisadora e bolsista de produtividade do CNPq, UFLA, Lavras, MG, Brasil. E-mail: fmoreira@dcs.ufla.br

* Author for correspondence 
experimental foi em blocos casualizados com oito tratamentos e quatro repetições, sendo as seis estirpes citadas e dois controles não inoculados, um com nitrogênio mineral $\left(70 \mathrm{~kg} \mathrm{ha}^{-1}\right)$ e outro sem nitrogênio mineral. Foram avaliados nodulação, crescimento, produtividade, acúmulo de nitrogênio na parte aérea e nos grãos e o teor de proteína bruta nos grãos. As estirpes em fase de seleção (UFLA 03-154 e UFLA 03-164) promoveram rendimento de grãos superiores aos obtidos pelas estirpes autorizadas como inoculantes (INPA 03-11B, BR 3267 e BR 3262). As inoculações com as estirpes UFLA 03-84, UFLA 03-154 e UFLA 03-164 proporcionam rendimento de grãos equivalentes ao controle com nitrogênio mineral $\left(796,51 \mathrm{~kg} \mathrm{ha}^{-1}\right)$, porém, semelhantes ao rendimento obtido com o controle sem nitrogênio mineral e sem inoculação, indicando boa eficiência simbiótica das populações nativas de rizóbio. A UFLA 03-154 destacou-se dos demais tratamentos com relação ao aumento de proteína bruta.

Palavras-chave: Vigna unguiculata (L.) Walp, Bradyrhizobium, fixação biológica de nitrogênio

\section{Introduction}

The cowpea [Vigna unguiculata (L.) Walp.] is very socioeconomically important and has remarkable strategic potential for the North and Northeast regions of Brazil, where it is a staple food and an alternative source of income, especially for low-income populations. The state of Piauí is the second largest producer of this crop, with approximately 242,500 ha planted and a yield of $64.8 \mathrm{t}$ (CONAB, 2008). However, the mean yield in the state is only approximately $448 \mathrm{~kg} \mathrm{ha}^{-1}$ (CONAB, 2008), reflecting the low level of technology used in its cultivation.

The use of biological inputs in place of industrialized chemical inputs has been increasing in agriculture. Thus, in several agroecosystems, the exploitation of biological nitrogen $(\mathrm{N})$ fixation (BNF) by adopting the practice of inoculating cowpea seeds with $\mathrm{N}_{2}$ fixing legume-nodulating bacteria (NFLNB) is an important strategy for increasing the yield of this crop, which can partially or completely replace $\mathrm{N}$ fertilization (SOARES et al., 2006; COSTA et al., 2011; FERREIRA et al., 2013; MARTINS et al., 2013), thus reducing production costs and the environmental impacts of improper fertilizer management. Soares et al. (2006), working with cowpea cultivar BR-14 Mulato in Perdões, Minas Gerais, reported yields of 949 and $950 \mathrm{~kg} \mathrm{ha}^{-1}$ in treatments inoculated with the strains INPA 03-11B and UFLA 03-84, respectively, which were similar to the control treatments with mineral $\mathrm{N}$ and higher than uninoculated controls without $\mathrm{N}$, which yielded only $341.80 \mathrm{~kg} \mathrm{ha}^{-1}$. Almeida et al.
(2010), in a trial conducted in the city of Teresina, Piauí, using the cowpea cultivar BR 17 Gurguéia inoculated with the strains INPA 03-11B, BR 3267 and BR 3262, also reported yields similar to the control treatment with mineral $\mathrm{N}$ and yields higher than the uninoculated control without $\mathrm{N}$.

Despite having ample BNF capabilities, positive responses are not always observed with the use of cowpea inoculants because a plant's response to inoculation is also determined by several biotic (BOGINO et al., 2008; MELLONI et al., 2006; MOREIRA; SIQUEIRA, 2006) and abiotic (HUNGRIA; VARGAS, 2000; FERREIRA et al., 2012) factors. The biotic factors include the high population density of indigenous rhizobia, which compete for nodule occupancy in the roots of host plants, potentially decreasing $\mathrm{N}_{2}$ fixation and, hence, the $\mathrm{N}$ supply to plants when nodules are induced by strains with varying $\mathrm{N}_{2}$ fixation efficiencies (BOGINO et al., 2008).

In addition to the effects of environmental and soil factors, the process of BNF is also affected by the genotypic characteristics of macro and microsymbionts (BELANE; DAKORA, 2009), resulting in differing responses in terms of host range, specificity and symbiotic efficiency. In cowpea cultivation, the lack of a response to inoculation has been reported by Guedes, Souza and Alves (2010) for strains INPA 03-11B, UFLA 03-84 and BR 3267 inoculated in the cowpea cultivar Nova Era in the state of Paraiba and by Zilli et al. (2009) for experimental crops in the state of Roraima using cowpea cultivar BRS Mazagão inoculated with 
strains INPA 03-11B, UFLA 03-84, BR 3262 and BR 3267. The absence of a favorable response has been attributed to the lack of adaptation of these inoculants to certain environmental and soil conditions and particularly to the competitiveness and symbiotic efficiency of native NFLNB populations already established in the soil. Thus, it is important to perform experiments in different soils and climatic conditions to determine the agronomic efficiency of approved inoculant strains and to identify novel strains that combine efficient BNF, adaptability to different environmental conditions, capacity to form symbioses with different host plants and high competitiveness for nodule occupancy.

The aim of this study was to evaluate the response of the cowpea cultivar BRS Guariba in southwest Piauí to inoculation with two previously selected rhizobial strains and four strains authorized as inoculants for this crop by the Brazilian Ministry of Agriculture, Livestock and Food Supply.

\section{Materials and Methods}

The test was conducted in an experimental field of the Agricultural College [Colégio Agrícola] (altitude $277 \mathrm{~m}, 09^{\circ} 04^{\prime}$ south latitude and $44^{\circ} 21^{\prime}$ west longitude) between July and September 2010 in dystrophic Yellow Latosol soil in Bom Jesus, Piauí. This field has a crop history that includes four consecutive years of Andropogon grass (Andropogon gayanus) cultivation followed by one year of maize (Zea mays) cultivation, and no inoculants of any type have been previously applied to the field. The experimental area is in a transition region between the Cerrado and Caatinga biomes.

According to Köppen (1931), the regional climate is type Aw, hot and humid with summer rains, characterized by two well-defined seasons, with rainy summers and dry winters, each lasting six months. The maximum and minimum temperatures and monthly pluvial precipitation are based on data from a weather station located approximately $100 \mathrm{~m}$ from the experimental area and are shown in Figure 1.

Figure 1. Maximum and minimum temperatures and monthly pluvial precipitation in the municipality of Bom Jesus, Piauí (2010).

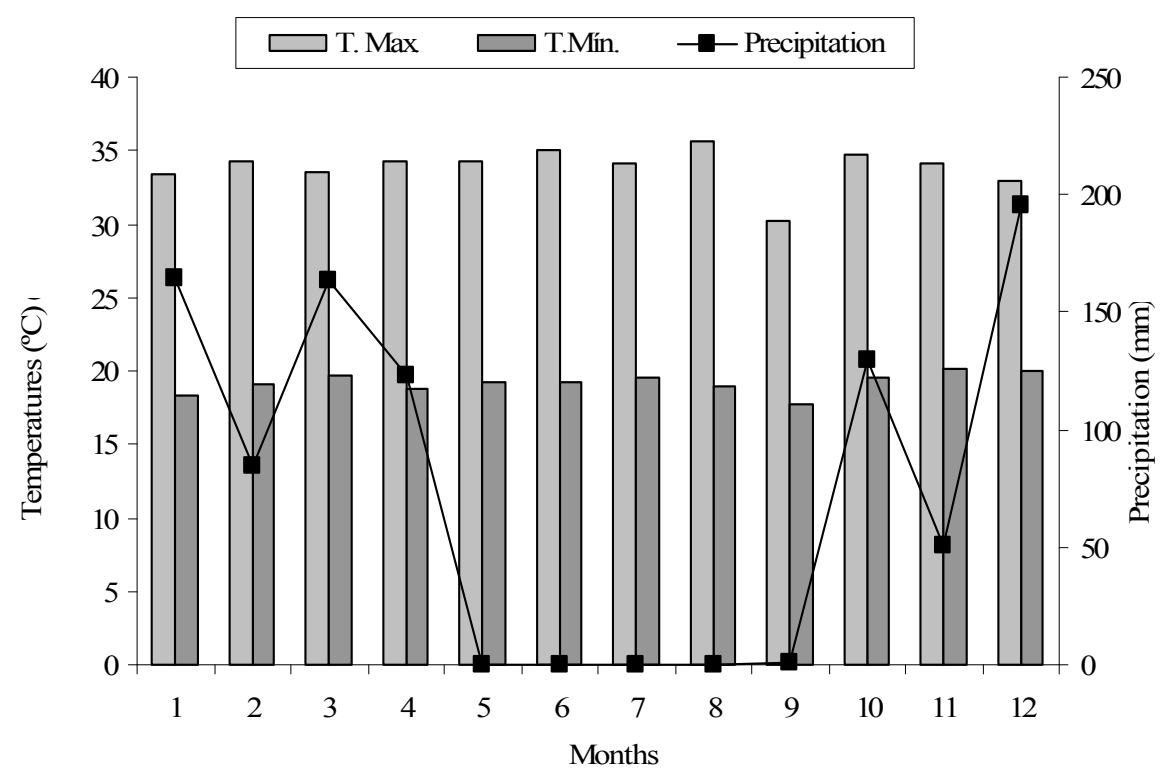

Source: Elaboration of the authors. 
The soil samples were collected at a depth of 0-20 $\mathrm{cm}$ prior to starting the experiment, and the analysis revealed the following characteristics: $\mathrm{pH}$ in $\mathrm{H}_{2} \mathrm{O}$ (1:2.5) 5.4; $\mathrm{P}$ (Mehlich1) $12.2 \mathrm{mg} \mathrm{dm}^{-3} ; \mathrm{K}^{+}$ $0.08 \mathrm{cmol}_{\mathrm{c}} \mathrm{dm}^{-3} ; \mathrm{Ca}^{2+}+\mathrm{Mg}^{2+} 1.7 \mathrm{cmol}_{\mathrm{c}} \mathrm{dm}^{-3} ; \mathrm{Na}^{+}$ $0.01 \mathrm{cmol}_{\mathrm{c}} \mathrm{dm}^{-3} ; \mathrm{Al}^{3+} 0.56 \mathrm{cmol}_{\mathrm{c}} \mathrm{dm}^{-3} ; \mathrm{H}+\mathrm{Al} 2.3$ $\mathrm{cmol}_{\mathrm{c}} \mathrm{dm}^{-3}$; SB $1.79 \mathrm{cmol}_{\mathrm{c}} \mathrm{dm}^{-3}$; effective CEC $2.35 \mathrm{cmol}_{\mathrm{c}} \mathrm{dm}^{-3}$; potential CEC $4.09 \mathrm{cmol}_{\mathrm{c}} \mathrm{dm}^{-3} ; \mathrm{m}$ $23.83 \%$; V 43.76\%; and organic matter $8.12 \mathrm{~g} \mathrm{~kg}^{-1}$.

The experimental design was randomized blocks with four replicates and eight treatments (forms of $\mathrm{N}$ supply). The treatments consisted of inoculations of cowpea cultivar BRS Guariba seeds with six strains of NFLNB, four of which are currently approved by the Ministry of Agriculture, Livestock and Food Supply as inoculants for crops (INPA 03-11B, UFLA 03-84, BR 3262 and BR 3267) and two that are in the selection phase (UFLA 03-164 and UFLA 03-154) (SOARES et al. 2014), along with two control treatments without inoculation: one without mineral $\mathrm{N}$ and the other with the

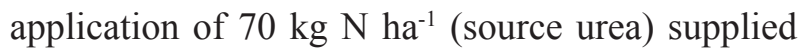
over two equal applications (one at planting and another 20 days after emergence). Strains INPA 0311B and UFLA 03-84 were isolated from Amazon soils and were identified as belonging to the genus Bradyrhizobium (SOARES et al., 2006). Strains BR 3262 and BR 3267, which also belong to the genus Bradyrhizobium, were isolated, respectively, from soils in Seropédica, Rio de Janeiro (ZILLI; NEVES; RUMJANEK, 1998) and the semi-arid northeast (MARTINS, 1996). The strains in the selection phase, UFLA 03-164 and UFLA 03-154, were isolated from bauxite mining soils undergoing rehabilitation and were identified as belonging to the genera Bradyrhizobium and Burkholderia, respectively (OLIVEIRA-LONGATTI et al., 2014).

The soil was prepared with a plow and a harrow. All treatments were given an application of $50 \mathrm{~kg}$ $\mathrm{ha}^{-1} \mathrm{P}_{2} \mathrm{O}_{5}$ (single superphosphate) and $30 \mathrm{~kg}$ ha ${ }^{-1}$ $\mathrm{K}_{2} \mathrm{O}$ (potassium chloride) based on results of soil fertility analyses, as recommended for this crop.

Inoculants were prepared using autoclaved peat in a ratio of 3:1 of peat and cultures in semi-solid 79 medium (FRED; WAKSMAN, 1928) in log phase (after five days of growth, with a minimum concentration of $10^{9}$ cells $\mathrm{g}^{-1}$ inoculant). Seeds were inoculated at a ratio of $500 \mathrm{~g}$ of inoculant per $50 \mathrm{~kg}$ of seed using a $10 \%$ sugar solution at a ratio of 10 $\mathrm{mL}$ per $12.0 \mathrm{~g}$ of inoculant.

The plots consisted of four 6-m-long rows, for a total area of $24 \mathrm{~m}^{2}$. The area used was formed by the two central rows in each plot. Sowing was performed immediately after inoculation using four seeds per hole. An inter-row spacing of $1.0 \mathrm{~m}$ and an in-row spacing of $0.2 \mathrm{~m}$ were adopted. Thinning was performed at 15 days after emergence, leaving two plants per hole.

The cultivation was irrigated using a center pivot irrigation system. The full irrigation depth was $416 \mathrm{~mm}$ during the crop cycle, and irrigation was performed daily. The irrigation depth calculation was based on the reference evapotranspiration estimated daily using the FAO Penman-Monteith parameterized method (ALLEN et al., 1998) and the crop coefficient $(\mathrm{Kc})$ estimated for the crop (Bastos et al., 2008).

In the first evaluation, conducted during flowering 40 days after planting, 10 plants from each plot were randomly collected from the area to assess the number of nodules per plant (NN), nodule fresh weight (NFW), nodule dry weight (NDW), shoot dry weight (SDW), $\mathrm{N}$ accumulation in shoots (NAS) and relative efficiency (RE).

In the second evaluation, performed at harvest, 10 plants from each plot were randomly collected from the area to assess the number of pods per plant (NPP), pod weight per plant (PWP), grain yield (YIELD), $\mathrm{N}$ accumulation in grain (NAG) and crude protein content in grain (CPC).

To determine the NDW and SDW, the nodules and shoots were placed in a $60^{\circ} \mathrm{C}$ forced air oven until they reached a constant weight. The relative efficiency of each strain was calculated using the following formula: $\mathrm{RE}=(\mathrm{SDW}$ inoculated $/$ 
SDW of the control fertilized with mineral N) * 100. To evaluate the grain yield, the moisture was adjusted to $13 \%$ (wet basis). The NAS and NAG were calculated by multiplying the weight of the SDW $(\mathrm{g})$ or YIELD $(\mathrm{kg})$ by its respective $\mathrm{N}$ content $(\%) / 100 . \mathrm{N}$ contents in shoots and grain were determined using the semi-micro Kjeldah method (LIAO, 1981). The CPC in grain was calculated by multiplying the $\mathrm{N}$ content in grain by a conversion factor (6.25).

Based on the Shapiro-Wilk test, the test data had a normal distribution. The NN, NFW and NDW were transformed by the square root of $\mathrm{Y}+0.5$ to adjust for normality. Subsequently, the data were subjected to analysis of variance using the statistical analysis system SISVAR, version 5.3 (FERREIRA; SISVAR, 2008), and when significance was detected among treatments, comparisons between means were performed using the Scott-Knott test at a 5\% probability.

\section{Results and Discussion}

In the first evaluation, conducted during flowering, the different forms of $\mathrm{N}$ supply significantly affected the NN, NFW and NDW (Table 1). For NN, the treatment inoculated with strain UFLA 03-84 had the highest value (23.74 nodules plant $\left.{ }^{-1}\right)$, clearly higher than the other treatments. Among inoculated treatments, the strains in the selection phase (UFLA 03-154 and UFLA 03-164) had NN values that were similar to each other but lower than the other strains. The uninoculated control without mineral $\mathrm{N}$ had an NN similar to the treatments inoculated with strains INPA 03-11B, BR 3262 and BR 3267. The control with mineral $\mathrm{N}$ had an NN below all inoculated treatments and the control without $\mathrm{N}$ (Table 1).

As for NFW and NDW, similar patterns were observed, i.e., the treatment inoculated with strain BR 3262 stood out from the other treatments, producing an average NFW and NDW of 406.33 and $294.63 \mathrm{mg} \mathrm{plant}^{-1}$, respectively (Table 1). Although the strains in the selection phase, UFLA 03-164 and UFLA 03-154, had lower NN values compared to the other inoculated treatments, they yielded good results in terms of NFW and NDW, similar to the performances of the approved inoculant strains (UFLA 03-84, INPA 03-11B and BR 3267) (Table $1)$.

Table 1. Mean values for the number of nodules per plant (NN), nodule fresh weight (NFW) and nodule dry weight (NDW) of cowpea (BRS Guariba) as a function of the different forms of $\mathrm{N}$ supply in southwest Piauí.

\begin{tabular}{lccc}
\hline Forms of N supply & NN & NFW & NDW \\
\hline INPA 03-11B & number plant $^{-1}$ & $138.50 \mathrm{~b}$ & $98.33 \mathrm{~b}$ \\
UFLA 03-84 & $16.60 \mathrm{~b}^{1}$ & $133.13 \mathrm{~b}$ & $87.13 \mathrm{~b}$ \\
BR 3267 & $23.74 \mathrm{a}$ & $178.40 \mathrm{~b}$ & $121.42 \mathrm{~b}$ \\
BR 3262 & $14.57 \mathrm{~b}$ & $406.33 \mathrm{a}$ & $294.63 \mathrm{a}$ \\
UFLA 03-154 & $14.40 \mathrm{~b}$ & $135.07 \mathrm{~b}$ & $96.85 \mathrm{~b}$ \\
UFLA 03-164 & $9.31 \mathrm{c}$ & $184.70 \mathrm{~b}$ & $129.33 \mathrm{~b}$ \\
With N & $6.98 \mathrm{c}$ & $6.10 \mathrm{c}$ & $2.60 \mathrm{c}$ \\
Without N & $1.82 \mathrm{~d}$ & $116.65 \mathrm{~b}$ & $86.83 \mathrm{~b}$ \\
\hline CV (\%) & $12.61 \mathrm{~b}$ & 17.27 & 17.85 \\
\hline
\end{tabular}

${ }^{1}$ Means followed by the same letter in the column do not differ by the Scott-Knott test at a 5\% probability.

Source: Elaboration of the authors. 
Costa et al. (2011) also reported similar mean NFW and NDW values between the strain in the selection phase (UFLA 03-164) and the approved inoculants (UFLA 03-84, INPA 03-11B and BR 3267) when inoculated on the cowpea cultivar BR 17 Gurguéia in tests conducted in Bom Jesus, Piauí. Guedes, Souza and Alves (2010), in an experiment conducted in Pombal, Paraíba evaluating the efficiency of the strain UFLA 03-154, compared strains UFLA 03-84, INPA 03-11B and BR 3267 inoculated on the cowpea cultivar Nova ERA and reported the highest values of NN and NFW for the treatment inoculated with strain UFLA 03-154. Based on these results, the strains in the selection phase, UFLA 03-164 and UFLA 03-154, show promise for use as cowpea inoculants, given that the nodulation capacity is an important characteristic that needs to be evaluated in a selection and recommendation process for new strains as part of the agronomic efficiency evaluation protocol for rhizobial strains used as commercial inoculants (BRAZIL, 2011).

As observed for $\mathrm{NN}$, the uninoculated control without mineral $\mathrm{N}$ yielded NFW and NDW that were equal to most of the inoculated treatments, whereas the control with mineral $\mathrm{N}$ reduced nodulation (Table 1). The similarity between the nodulation of cowpea for the uninoculated control without mineral $\mathrm{N}$ and the inoculated treatments indicates the nodulation capacity of the native rhizobia populations. The cell density of the inoculant is not the only factor responsible for promoting efficient nodulation, but other events, such as effects from environmental and soil factors and the survivability of each NFLNB strain, also play roles (BOGINO et al., 2008; MOREIRA; SIQUEIRA, 2006). In contrast, the lowest values of NN, NFW and NDW were observed in the treatment with mineral $\mathrm{N}$, indicating the dominant role this nutrient has on cowpea nodulation, a fact that has been observed in other studies with cowpea in field conditions (SOARES et al., 2006; COSTA et al., 2011; MARTINS et al., 2013). Costa et al. (2011) reported results that were similar to those obtained in the present study, in which most of the inoculated treatments exhibited nodulation levels equal to uninoculated treatments without mineral $\mathrm{N}$ and higher than the controls with mineral $\mathrm{N}$.

With respect to the SDW and RE, there were no significant differences between the forms of $\mathrm{N}$ supply (Table 2), suggesting that cowpea symbiosis with the strains used here and the native rhizobial populations was efficient in supplying $\mathrm{N}$ to the crop, promoting plant development to levels that are similar to those that received $\mathrm{N}$ fertilization at 70 $\mathrm{kg} \mathrm{N} \mathrm{ha-1}$. This result demonstrates the capacity of native populations to establish efficient symbioses with cowpea, legume that is considered promiscuous (GUIMARÃES et al., 2012; JARAMILLO et al., 2013), and is consistent with the results observed in other field trials in different regions of Brazil (GUEDES; SOUZA; ALVES, 2010; COSTA et al., 2011).

Regarding the variable NAS, the strain BR 3267 was notable, displaying a productivity that was superior to all the other inoculated treatments and similar to the control treatment with mineral $\mathrm{N}$. The other strains showed NAS values equal to the uninoculated control without mineral N (Table 2). This result indicates that strain BR 3267 has a higher efficiency compared to the other strains and to the native rhizobia populations in terms of $\mathrm{N}_{2}$ fixation and $\mathrm{N}$ supply, via BNF, at this stage of cowpea development.

In the second evaluation, at harvest, the forms of $\mathrm{N}$ supply affected all variables tested (Table 3 ). For the variable NPP, strain UFLA 03-84 performed the best among the inoculated treatments, with the highest yield (8.62 pods plant $\left.{ }^{-1}\right)$, and thus exhibited better performance than the control treatment with mineral N. Strain INPA 03-11B was the least efficient, yielding the lowest number (3.75 pods plant $\left.{ }^{-1}\right)$ (Table 3). The PWP ranged from 8.85 (treatment inoculated with the strain INPA 03-11B) to 18.42 g plant ${ }^{-1}$ (uninoculated control without mineral $\mathrm{N}$ ) 
(Table 3). Among the inoculated treatments, the two strains in the selection phase, UFLA 03-154 and UFLA 03-164, were notable, with mean yields of 16.14 and 16.36 g plant -1 , respectively, values that are higher than those obtained with strains currently approved as cowpea inoculants (INPA 03-11B, UFLA 03-84, BR 3267 and BR 3262).

Table 2. Mean values of shoot dry weight (SDW), relative efficiency (RE) and nitrogen (N) accumulation in shoots (NAS) of cowpea (BRS Guariba) as a function of the different forms of N supply in the soil in southwest Piauí.

\begin{tabular}{lccc}
\hline Forms of N supply & SDW & RE & NAS \\
\hline & g plant $^{-1}$ & $---\%--$ & mg plant $^{-1}$ \\
\hline INPA 03-11B & $15.23 \mathrm{a}^{1}$ & $86.24 \mathrm{a}$ & $426.54 \mathrm{~b}$ \\
UFLA 03-84 & $14.97 \mathrm{a}$ & $81.88 \mathrm{a}$ & $361.22 \mathrm{~b}$ \\
BR 3267 & $20.17 \mathrm{a}$ & $112.71 \mathrm{a}$ & $563.56 \mathrm{a}$ \\
BR 3262 & $17.06 \mathrm{a}$ & $96.64 \mathrm{a}$ & $390.64 \mathrm{~b}$ \\
UFLA 03-154 & $13.97 \mathrm{a}$ & $79.00 \mathrm{a}$ & $384.25 \mathrm{~b}$ \\
UFLA 03-164 & $15.39 \mathrm{a}$ & $86.61 \mathrm{a}$ & $407.23 \mathrm{~b}$ \\
With N & $18.31 \mathrm{a}$ & $100.00 \mathrm{a}$ & $496.78 \mathrm{a}$ \\
Without N & $17.88 \mathrm{a}$ & $98.75 \mathrm{a}$ & $358.54 \mathrm{~b}$ \\
\hline CV (\%) & 16.87 & 16.37 & 19.51 \\
\hline
\end{tabular}

${ }^{1}$ Means followed by the same letter in the column do not differ by the Scott-Knott test at a 5\% probability.

Source: Elaboration of the authors.

Guedes, Souza and Alves (2010) reported mean NPP values for cowpea (cultivar Nova Era) higher than those obtained in the present study, ranging from 10 to 17.55 pods plant $^{-1}$ in treatments inoculated with strains BR 3267 and UFLA 03-154, respectively. However, Costa et al. (2011) reported lower values in cultivar BR 17 Gurguéia for treatments inoculated with strains UFLA 03-84, BR 3267 and UFLA 03-164, which yielded averages of $5.35,5.01$ and 5.37 pods plant ${ }^{-1}$, respectively. Ferreira et al. (2013) reported PWP values for the cultivar BR 17 Gurguéia ranging between 14 and $40 \mathrm{~g} \mathrm{plant}^{-1}$ in treatments inoculated with strains BR 3262 and UFLA 03-84, respectively. These differences observed between the present study and those cited studies could be related to the genetic potential of each cowpea cultivar, the interaction between symbionts, and other factors, such as the effects of environmental factors.

As for NAG, the two strains in the selection phase (UFLA 03-154 and UFLA 03-164) and strain UFLA 03-84 stood out from the other strains (Table
3), yielding $\mathrm{N}$ accumulations similar to those found in the control with mineral N. Similarly, the native rhizobial populations (uninoculated control without mineral $\mathrm{N}$ ) were also quite efficient, presenting NAG levels similar to those of the control with mineral $\mathrm{N}$ and higher than strains INPA 03-11B, BR 3267 and BR 3262.

Regarding CPC in grain, strain UFLA 03-154 stood out from the other treatments, yielding a mean content of $25.15 \%$ (Table 3 ). As the CPC reflects the total $\mathrm{N}$ absorbed by plants, strain UFLA 03-154 was efficient in fixing this nutrient, showing a higher performance than the control that received a $70 \mathrm{~kg}$ $\mathrm{ha}^{-1}$ application of mineral $\mathrm{N}$.

The grain yield ranged between 516.78 and $962.27 \mathrm{~kg} \mathrm{ha}^{-1}$ for treatments inoculated with stains BR 3267 and UFLA 03-164, respectively (Table 3). Strain UFLA 03-84, the strains in the selection phase (UFLA 03-154 and UFLA 03-164) and the uninoculated control without mineral $\mathrm{N}$ also stood out from the other treatments, promoting yields equal to those obtained with the $\mathrm{N}$ fertilized control 
(70 $\left.\mathrm{kg} \mathrm{ha}^{-1} \mathrm{~N}\right)$. This result suggests that biological $\mathrm{N}_{2}$ fixation is able to fully replace the $\mathrm{N}$ fertilizer (70 $\mathrm{kg} \mathrm{ha}^{-1}$ ) required for cowpea productivity, enabling the cultivation of this crop at lower production costs and reduced environmental impacts due to the inappropriate handling of $\mathrm{N}$ fertilizers.

Table 3. Mean values of the number of pods per plant (NPP), pod weight per plant (PWP), nitrogen (N) accumulation in grain (NAG), crude protein content in grain (CPC) and grain yield (YIELD) of the cowpea cultivar (BRS Guariba) as a function of different forms of $\mathrm{N}$ supply in the soil in southwest Piauí.

\begin{tabular}{lccccc}
\hline Forms of N supply & NPP & PWP & NAG & CPC & YIELD \\
\hline & number plant & \\
\hline INPA 03-11B & $3.75 \mathrm{c}^{1}$ & $8.85 \mathrm{c}$ & $19.65 \mathrm{~b}$ & $20.32 \mathrm{c}$ & $627.45 \mathrm{~b}$ \\
UFLA 03-84 & $8.62 \mathrm{a}$ & $13.42 \mathrm{~b}$ & $27.92 \mathrm{a}$ & $21.37 \mathrm{c}$ & $848.53 \mathrm{a}$ \\
BR 3267 & $6.04 \mathrm{~b}$ & $14.38 \mathrm{~b}$ & $17.40 \mathrm{~b}$ & $21.96 \mathrm{c}$ & $516.78 \mathrm{~b}$ \\
BR 3262 & $6.76 \mathrm{~b}$ & $12.52 \mathrm{~b}$ & $18.01 \mathrm{~b}$ & $21.69 \mathrm{c}$ & $539.40 \mathrm{~b}$ \\
UFLA 03-154 & $6.09 \mathrm{~b}$ & $16.14 \mathrm{a}$ & $28.43 \mathrm{a}$ & $25.15 \mathrm{a}$ & $832.07 \mathrm{a}$ \\
UFLA 03-164 & $6.54 \mathrm{~b}$ & $16.36 \mathrm{a}$ & $31.98 \mathrm{a}$ & $20.66 \mathrm{c}$ & $962.27 \mathrm{a}$ \\
With N & $5.93 \mathrm{~b}$ & $13.17 \mathrm{~b}$ & $30.57 \mathrm{a}$ & $23.18 \mathrm{~b}$ & $796.51 \mathrm{a}$ \\
Without N & $9.32 \mathrm{a}$ & $18.42 \mathrm{a}$ & $29.07 \mathrm{a}$ & $21.18 \mathrm{c}$ & $892.26 \mathrm{a}$ \\
\hline CV (\%) & 14.97 & 18.58 & 16.07 & 4.89 & 15.17 \\
\hline
\end{tabular}

${ }^{1}$ Means followed by the same letter in the column do not differ by the Scott-Knott test at a $5 \%$ probability.

Source: Elaboration of the authors.

The lack of advantages of inoculation treatments compared to the uninoculated control without mineral $\mathrm{N}$ in terms of cowpea grain yield can be explained by the effect of environmental and soil conditions on the symbiotic efficiency of the inoculants and by cowpea having low symbiotic specificity and being capable of establishing symbioses with several species of native NFLNB (GUIMARÃES et al., 2012; JARAMILLO et al., 2013). In some cases, the low specificity of this crop toward microsymbionts may be limiting the technological exploitation of inoculations with different rhizobial strains, as NFLNB established in the soil are adapted to the local environmental and soil conditions and are thus more competitive, even though they have variable BNF efficiencies. In the present study, the native rhizobial populations were very efficient, fixing an $\mathrm{N}$ supply capable of increasing cowpea yield to levels similar to the application of $70 \mathrm{~kg} \mathrm{ha}^{-1}$ mineral $\mathrm{N}$. This fact was also observed by Costa et al. (2011), who obtained similar cowpea cultivar BR 17 Gurguéia yields between treatments inoculated with strains INPA
03-11B and UFLA 03-154, control treatment with mineral $\mathrm{N}$ (70 $\left.\mathrm{kg} \mathrm{N} \mathrm{ha}^{-1}\right)$ and uninoculated control treatment without $\mathrm{N}$ in a study conducted in southwest Piauí. These data indicate that evaluating the occurrence and efficiency of native NFLNB populations in the southwest region of Piauí can provide a selection of rhizobial strains that provide sufficient BNF for use as inoculants.

Results similar to those obtained in this study were also observed in field trials in different regions of Brazil. Guedes, Souza and Alves (2010), working with strains INPA 03-11B, UFLA 03-84 and BR 3267 inoculated onto the cowpea cultivar Nova Era in the state of Paraíba, reported similar grain yields between inoculated treatments, uninoculated control treatments without mineral $\mathrm{N}$ and control treatments with mineral $\mathrm{N}\left(70 \mathrm{~kg} \mathrm{ha}^{-1}\right)$. Zilli et al. (2009), for experimental crops in a Cerrado area in the state of Roraima using the cowpea cultivar BRS Mazagão, reported similar yields among all inoculated treatments (INPA 03-11B, UFLA 03-84, BR 3262, BR 3267 and BR 3299), two N 
fertilizer control treatments (50 and $\left.80 \mathrm{~kg} \mathrm{ha}^{-1}\right)$ and the control treatment without mineral N. However, studies conducted in other regions demonstrated that the use of inoculation technology can provide significant increases in cowpea yields compared to yields achieved without the use of this technology. Lacerda et al. (2004) and Soares et al. (2006) were the first to demonstrate the increased yields achieved for the cowpea cultivar BR-14 Mulato inoculated with strains UFLA 03-84 and INPA 0311B compared to uninoculated control treatments without mineral $\mathrm{N}$ in field trials in the state of Minas Gerais. Using experimental crops with the cowpea cultivar BRS Amapá in the state of Roraima, Zilli et al. (2006) reported that strain BR 3267 was able to provide grain yields similar to yields achieved with the application of $50 \mathrm{~kg} \mathrm{ha}^{-1} \mathrm{~N}$ at planting or $80 \mathrm{~kg} \mathrm{ha}^{-1} \mathrm{~N}$ over two applications and superior to yields achieved for uninoculated control treatments without mineral $\mathrm{N}$. These differences in yield can be explained by the variable symbiotic efficiencies of native NFLNB populations established in the soil and other factors, such as environmental and soil conditions specific to each study area and differences in the yield potential of different cowpea cultivars.

Although it was not significantly different than the uninoculated control treatment without $\mathrm{N}$, the treatment inoculated with strain UFLA 03164 showed an increased yield of $70 \mathrm{~kg} \mathrm{ha}^{-1}$, thus demonstrating the potential of this strain to be used as a cowpea inoculant. Notably, the mean yields achieved in this study were higher than the mean yield in the state of Piauí (448 $\mathrm{kg} \mathrm{ha}^{-1}$ ). However, these increases in yield should not be attributed solely to the effects of biological $\mathrm{N}_{2}$ fixation because additional technologies, including irrigation and phosphorus (50 kg ha-1 $\mathrm{P}_{2} \mathrm{O}_{5}$ ) and potassium (30 kg $\mathrm{ha}^{-1} \mathrm{~K}_{2} \mathrm{O}$ ) fertilization, were also used, which are not commonly used for the cultivation of this crop in most producing regions of the state of Piauí.

\section{Conclusions}

The inoculations with strains in the selection phase (UFLA 03-154 and UFLA 03-164) resulted in higher yields than inoculations with strains approved as inoculants for cowpea cultivation (INPA 03-11B, BR 3267 and BR 3262).

The native rhizobia populations produced yields that were similar to control plants fertilized with $\mathrm{N}$ and to plants inoculated with strains UFLA 03-84, UFLA 03-154 and UFLA 03-164, indicating that in these soils, inoculation and $\mathrm{N}$ fertilization are not necessary.

\section{Acknowledgments}

The authors thank the National Council for Scientific and Technological Development [Conselho Nacional de Desenvolvimento Científico e Tecnológico (CNPq)], the Ministry of Agriculture, Livestock and Food Supply [Ministério da Agricultura Pecuária e Abastecimento (MAPA)] and the Department of Agricultural Development [Secretaria de Desenvolvimento da Agricultura (SDA)] for providing financial assistance for the project (CNPq/MAPA edital 64- process 5786352008/9) and the Agricultural College of Bom Jesus [Colégio Agrícola de Bom Jesus] for use of the experimental area.

\section{References}

ALMEIDA, A. L. G.; ALCÂNTARA, R. M. C. M.; NÓBREGA, R. S. A.; LEITE, L. F. C.; SILVA, J. A. L.; NÓBREGA, J. C. A. Produtividade do feijão-caupi cv BR 17 Gurguéia inoculado com bactérias diazotróficas simbióticas no Piauí. Revista Brasileira de Ciências Agrárias, Recife, v. 5, n. 3, p. 364-36, 2010.

ALLEN, R. G.; PEREIRA, L. S.; RAES, D.; SMITH, M. Crop evapotranspiration, guidelines for computing crop water requirements. Rome: FAO, 1998. 300 p. (FAO. Irrigation and Drainage Paper, 56).

BASTOS, E. A.; FERREIRA, V. M.; SILVA, C. R.; ANDRADE JÚNIOR, A. S. Evapotranspiração e coeficiente de cultivo do feijão-caupi no Vale do Gurguéia, Piauí. Irriga, Botucatu, v. 3, n. 2, p. 182-190, 2008. 
BELANE, A. K.; DAKORA, F. D. Measurement of $\mathrm{N}_{2}$, fixation in 30 cowpea (Vigna unguiculata L . Walp.) genotypes under field conditions in Ghana, using the $15 \mathrm{~N}$ natural abundance technique. Symbiosis, Philadelphia, v. 48, n. 1, p. 47-56, 2009.

BOGINO, P.; BANCHIO, E.; BONFIGLIO, C.; GIORDANO, W. Competitiveness of a Bradyrhizobium sp. strain containing indigenous rhizobia. Systematic \& Applied Microbiology, Washington, v. 56, n. 1, p. 66-72, 2008.

BRASIL. Ministério da Agricultura, Pecuária e Abastecimento. Instrução normativa $\mathrm{n}^{\circ} 13$, de 24 de março de 2011. Secretaria de Defesa Agropecuária. Diário Oficial [da] União, Pará, 25 mar. 2011. Seção 1, p. 3-7. Disponível em: <http://www.jusbrasil.com. br/diarios/25585722/pg-3-secao-1-diario-oficial-dauniao-dou-de-25-03-2011>. Acesso em: 12 dez. 2011.

COMPANHIA NACIONAL DE ABASTECIMENTO CONAB. Avaliação da safra agrícola 2009/2010, quarto levantamento. Rio de Janeiro: CONAB, 2008. 16 p.

COSTA, E. M.; NÓBREGA, R. S. A.; MARTINS, L. V.; AMARAL, F. H. C.; MOREIRA, F. M. S. Nodulação e produtividade de Vigna unguiculata (L.) Walp. por cepas de rizóbio em Bom Jesus, PI. Revista Ciência Agronômica, Fortaleza, v. 42, n. 1, p. 1-7, 2011.

FERREIRA, D. F. SISVAR: um programa para análises e ensino de estatística. Revista Symposium, Lavras, v. 6, n. 2, p. 36-41, 2008.

FERREIRA, L. V. M.; NOBREGA, R. S. A.; NOBREGA, J.C.A.; AGUIAR, F. L.; MOREIRA, F. M. S.; PACHECO, L. P. Biological nitrogen fixation in production of Vigna unguiculata (L.) Walp family farming in Piauí, Brazil. Journal of Agricultural Science, Canadian, v. 5, n. 4, p. 153-160, 2013.

FERREIRA, P. A. A.; BOMFETI, C. A.; SOARES, B. L.; MOREIRA, F. M. S. Efficient nitrogen-fixing Rhizobium strains isolated from Amazonian soils are highly tolerant to acidity and aluminium. World Journal Microbiol Biotechnology, Oxford, v. 28, n. 5, p. 1947-59, 2012.

FRED, E. B.; WAKSMAN, S. A. Laboratory manual of general microbiology. New York: McGraw-Hill Book Company, 1928. 143 p.

GUEDES, G. N.; SOUZA, A. S.; ALVES, L. S. Eficiência agronômica de inoculantes em feijão-caupi no município de Pombal-PB. Revista Verde, Fortaleza, v. 5, n. 4, p. 8296, 2010.

GUIMARÃES, A. A.; JARAMILlO, P. M. D.; NÓBREGA, R. S. A.; FLORESTINO, L. A.; SILVA, K. B.; MOREIRA, F. M. S. Genetic and symbiotic diversity of nitrogen fixing bacteria isolated from agricultural soils in the western Amazon by using cowpea as the trap plant. Applied and Environmental Microbiology, Washington, v. 78, n. 18, p. 6726-6733, 2012.

HUNGRIA, M.; VARGAS, M. A. Environmental factors affecting $\mathrm{N}_{2}$ fixation in grain legumes in the tropics with an emphasis on Brazil. Field Crops Research, Amsterdam, v. 65, n. 2, p. 51-164, 2000.

JARAMILLO, P. M. D.; GUIMARÃES, A. A.; FLORENTINO, L. A.; SILVA, K. B.; NÓBREGA, R. S. A.; MOREIRA, F. M. S. Symbiotic nitrogenfixing bacterial populations trapped from soils under agroforestry systems in the Western Amazon. Scientia Agricola, Piracicaba, v. 70, n. 6, p. 397-404, 2013.

KÖPPEN, W. Grundriss der klimakunde. Berlin: Walter D. E. Guyter \& Co, 1931. 390 p.

LACERDA, A. M.; MOREIRA, F. M. S.; ANDRADE, M. J. B.; SOARES, A. L. L. Efeito de estirpes de rizóbio sobre a nodulação e produtividade do feijão-caupi. Revista Ceres, Viçosa, v. 51, n. 293, p. 67-82, 2004.

LIAO, C. F. H. Devarda's alloy method for total nitrogen determination. Soil Science Society of America Journal, Madison, v. 45, n. 5, p. 852-855, 1981.

MARTINS, L. M. V. Características ecológicas e fisiológicas de rizóbios de caupi [Vigna unguiculata (L.) Walp] isolados a partir de solos da região Nordeste do Brasil. 1996. Dissertação (Mestrado em Agronomia) - Universidade Federal Rural do Rio de Janeiro, Seropédica.

MARTINS, R. N. L.; NÓBREGA, R. S. A.; SILVA, A. F. T.; NÓBREGA, J. C. A.; AMARAL, F. H. C.; COSTA, E. M.; LUSTOSA FILHO, J. F.; MARTINS, L. V. Nitrogênio e micronutrientes na produção de grãos de feijão-caupi inoculado. Semina: Ciências Agrárias, Londrina, v. 34, n. 4, p. 1577-1586, 2013.

MELLONI, R.; MOREIRA, F. M. S.; NÓBREGA, R. S. A.; SIQUEIRA, J. O. Eficiência e diversidade fenotípica de bactérias diazotróficas que nodulam caupi (Vigna unguiculata L. Walp.) e feijoeiro (Phaseolus vulgaris L.) em solos de mineração de bauxita em reabilitação. Revista Brasileira de Ciência do Solo, Viçosa, v. 20, n. 2, p. 235-246, 2006.

MOREIRA, F. M. S.; SIQUEIRA, J. O. Microbiologia e bioquímica do solo. 2. ed. Lavras: UFLA, 2006. 729 p.

OLIVEIRA-LONGATTI, S. M.; MARRA, L. M.; L SOARES, L. B.; BOMFETI, C. A.; SILVA, K.; AVELAR FERREIRA, P. A. A.; MOREIRA, F. M. S. Bacteria isolated from soils of the western Amazon and from rehabilitated bauxite-mining areas have potential as plant growth promoters. World Journal of Microbiology \& Biotechnology, Oxford, v. 30, n. 4, p. 1239-1250, 2014. 
SOARES, A. L. L.; PEREIRA, J. P. A. R.; FERREIRA, P. A. A.; VALE, H. M. M.; LIMA, A. S.; ANDRADE, M. J. B.; MOREIRA, F. M. S. Eficiência agronômica de rizóbios selecionados e diversidade de populações nativas nodulíferas em Perdões (MG). I - caupi. Revista Brasileira de Ciência do Solo, Viçosa, MG, v. 30, n. 5, p. 795-802, 2006.

SOARES, B. L.; FERREIRA, P. A. A.; OLIVEIRALONGATTI, S. M.; MARRA, L. M.; RUFINI, M.; ANDRADE, M. J. B.; MOREIRA, F. M. S. Cowpea symbiotic efficiency, $\mathrm{pH}$ and aluminum tolerance in nitrogen-fixing bacteria. Scientia Agricola, Piracicaba, v. 71, n. 3, p. 171-180, 2014.
ZILLI, J. E.; NEVES, M. C. P.; RUMJANEK, N. G. Signalling specificity of rhizobia isolated from nodules of Phaseoleae and Indigofereae tribes. Anais da Academia Brasileira de Ciências, Rio de Janeiro, v. 70, n. 4, p. 743$750,1998$.

ZILLI, J. E.; MARSON, L. C.; MARSON, B. F.; RUMJANEK, N. G.; XAVIER, G. R. Contribuição de estirpes de rizóbio para o desenvolvimento e produtividade de grãos de feijão-caupi em Roraima. Acta Amazonica, Manaus, v. 39, n. 4, p. 49-758, 2009.

ZILLI, J. E.; MARSON, L. C.; XAVIER, G. R.; RUMJANEK, N. G. Avaliação de estirpes de rizóbio para a cultura do feijão-caupi em Roraima. Boa Vista: Embrapa Roraima, 2006. 8 p. (Comunicado técnico, 1). 
